\title{
Sustainable Growth in SMEs: A Review from the Malaysian Perspective
}

\author{
Tairuddin Yusoff ${ }^{1}$, Sazali A. Wahab ${ }^{2}$, Ahmad S. A. Latiff ${ }^{2}$, Suzana I. W. Osman ${ }^{3}$, Nur F. M. Zawawi ${ }^{1}$ \\ \& Syed A. Fazal ${ }^{1,4}$ \\ ${ }^{1}$ Faculty of Entrepreneurship and Business, Universiti Malaysia Kelantan, Kota Bharu, Kelantan, Malaysia \\ ${ }^{2}$ Putra Business School, 43400 UPM Serdang, Selangor Darul Ehsan, Malaysia \\ ${ }^{3}$ Faculty of Administrative Science and Policy Studies, Universiti Teknologi MARA, Shah Alam, Malaysia \\ ${ }^{4}$ Novel Global Community Educational Foundation (NGCEF), Australia \\ Correspondence: Tairuddin Yusoff, Faculty of Entrepreneurship and Business, Universiti Malaysia Kelantan, Kota \\ Bharu, Kelantan, Malaysia.
}

Received: June 26, 2018 Accepted: July 29, 2018 Online Published: August 21, 2018

doi:10.5539/jms.v8n3p43 URL: https://doi.org/10.5539/jms.v8n3p43

\begin{abstract}
The importance of Small and Medium Enterprises (SMEs) contributions to the nations' economies in the world is an undebatable fact. The same applies to Malaysia with $98.5 \%$ of the total business establishments being SMEs; contributing to $65.3 \%$ of total employment and $36.3 \%$ of GDP. Supports from the Government are never fading with huge allocations of budget every year but yet registering high failure rate. Sustainable growth of SMEs is long overdue. The awareness of the importance of sustainable growth of SMEs has resulted in the presence of various definitions and concepts of sustainable growth. This paper seeks to explore the literature on long-term and sustainable growth for SMEs and the enhanced knowledge on this area willbe aguidance to the policy makers, supporting agencies, advisors, entrepreneurs and academicians to seriously develop an all-encompassing model for sustainable growth of SMEs. This paper suggests an integrated sustainable growth model of SMEs with four dimensions of the economic factors.
\end{abstract}

Keywords: small medium enterprises, sustainable growth, Malaysia

\section{Introduction}

Both theoretical and empirical opinions, suggestions and results supporting the significance contribution of SMEs to the economic growth of all the nations in the world including Malaysia are abundant (Khan \& Khalique, 2014; Abdullah \& Rosli, 2015; Ong, 2015; Madanchian, Hussein, Nordin, \& Taherdoost, 2016; Musa \& Chinniah, 2016). SMEs in Malaysia accounted for $98.5 \%$ of total establishments employing $65.3 \%$ of total workforce in 2016 and contributing 36.6\% to the country's GDP (National SME Development Corporation (NSDC), 2017; Department of Statistics, 2017). Recognizing the contributions of SMEs to the Malaysian economies, and with the intention to promote their performance, the government has introduced numerous programs (Musa \& Chinniah, 2016; NSDC, 2017) including both non-financial and financial supports that involved large amount of budget allocation year in, year out. However the contribution of SMEs to the nation's GDP has not increased very much, leveling at 32\% level in 2010 to $36.6 \%$ in 2016 (NSDC, 2017).

This performance is contributed by a relatively high rate of failure. It has been registered in all parts of the world that many SMEs were unable to sustain their businesses with significant failures of almost $50 \%$ within the first five years of establishments and two-third failing within the first ten years of establishments (Small Business Administration (SBA), 2012; De Geest, Follmer, Walter \& O'Boyle, 2015). According to SBA $(2014,2017)$ and the latest statistics as at March 2016 as reported by the Bureau of labour Statistics (2016), the failure rate of 50\% of the firms in United States survive after 5 years, and only one-third (1/3) survive more than 10 years have been very consistent over the years. Those experiences are shared by SMEs in Malaysia with many of them failed within the first 5 years (Kee-Luen, Thiam-Yong, \& Seng-Fook, 2013) with some $60 \%$ failure rate being noted by Chong (2012) and, Ahmad and Seet (2009). According to the SME census 2011 reported in the SME master plan 2012-2020, 42\% of the SMEs that existed in 2000 failed to survive through 2005 (National SME Development Council (NSDC), 2014). Recently, during the launching of the entrepreneurship challenge, AmBank's Managing 
Director said that almost $80 \%$ of SMEs do not survive the first three years (Bernama, 2017). Jebna and Baharuddin (2013) mentioned that even without reliable data, the failure rate of SMEs is expected to be higher. Due to unavailability of other published reports on failure rate of SMEs in Malaysia, those numbers would represent reliable indicator on the obvious challenges on the sustainable growth of SMEs. Hence in this study the objective is to explore the literature on sustainable growth for SMEs.

The paper is structured to focus on the concept of sustainable development, defining growth and the interplay between sustainability and sustainable growth. It is envisaged that this paper would further enhance the knowledge on this area that will guide the policy makers, supporting agencies, advisors, entrepreneurs and academicians to seriously develop an all-encompassing model for sustainable growth of SMEs, particularly in the Malaysian context.The paper is structured to start with the Introduction; underlining the significance of SMEs and their sustainable growth in context of Malaysia, an emerging economy. The second section, Literature Review, attempts to explain thegeneral concept of sustainability, define sustainable growth, followed by the application and adaptation of sustainable growth in SMEs before the reaching the third and final section; i.e. is Conclusion.

\section{Literature Review}

\subsection{The Concept of Sustainability}

The term sustainabledevelopmentwas first mentioned in the report on the limits of growthpublished in 1972 (Gunilla, 2014) and later resonated in the Brundtland Report in 1987 and published in the World Commission on Environment and Development (WCED) in 1989 (Borim-de-Souza, Balbinot, Travis, Munck, \& Takahashi, 2015), in which it was defined as current development without compromising future needs (Barkemeyer, Holt, Preuss, \& Tsang, 2014).There are two main concepts of Brundtland report; firstly the needs for the poor, and secondly, the limit on the environment to meet future needs (Barkemeyer et al., 2014).

However there are two noticeable aspects of the original themes as defined in the Bundtland Report that have been shifted: a) from human needs to human rights; b) from the original trade-off between the two aspects of environmental and social to more focus on environment at the expense of social issues (Barkemeyer et al., 2014). The emphasis of the world's poor as promoted in the Bridtland is not given much attention. The above are some of the common criticism being raised on sustainable development such as the vagueness of the concept of itself, its measuring difficulties, and its oxymoron nature of the perception of the concept (Barkemeyer et al, 2014). In the Malaysian SME Master Plan published by SME Corporation as the secretariat to National SME Development Council (NSDC), not much attention has been given to the environmental aspect of the development plan with more emphasize on the economic factor and social factors (Ong, 2015; NSDC, 2012).

The concept of sustainability is thus rooted from sustainable development (Lang \& Murphy, 2014). Although many use the terms sustainable development and sustainability interchangeably, they are inherently different, in which from the first perspective sustainable development is the journey or process to achieve sustainability (Lozano, 2008), and from second perspective, sustainability is the process to achieve sustainable development (Sartori, Latronico, \& Campos, 2014). Irrespective of the two contradicting perspectives, the research turns to address and explain sustainability (Sartori et al., 2014). 'Sustainability' has been treated as an umbrella term that covers various issues, concepts, practices and ways of thinking (Isada \& Isada, 2015) that are complex, and its concept remains theoretical and abstract leading to various research proposing different definition depending on how it is approached and perceived (Lozano, 2008; Jabareen, 2008; Barkemeyer et al., 2014; Owens \& Legere, 2015; Ratiu \& Anderson, 2015).

There is no consensus definition of sustainability that remains an ill-defined term (Galpin \& Hebard, 2015) with more than 70 different definitions (Lozano, 2008) being proposed by various studies (Barkemeyer et al., 2014; Owens \& Legere, 2015; Habidin, Zubir, Fuzi, Latip, \& Azma, 2015; Ratiu \& Anderson, 2015), depending on how the sustainability is approached and perceived (Lozano, 2008; Barkemeyer et al., 2014; Owens \& Legere, 2015). Even though the aim of sustainability is to secure intergenerational equity, its meaning yet remains elusive (Bansal \& DesJardine, 2014). The disagreement on the definitions and concepts further aggravated the misconceptions of the term leaving it as another theoretical and abstract concept (Jabareen, 2008). Borim-de-Souza et al. (2015) caution the existence of characteristic differentials of the term depending on who, how and why the terms are analyzed. The definitions of sustainability, a cross disciplinary concept, include human capability to maintain the well-being of all for long term period (Meng, 2015). In the New Economic Model (NEM) of Malaysia (National Economic Advisor Council (NEAC), 2009, p. 11), sustainability refers to attaining the current objectives "without compromising future generations by effective stewardship and preservation of the natural environment and non-renewable resources". The term sustainability has been 
overused and misused by researchers (Prabawani, 2013) depending on the actors (Ratiu \& Anderson, 2015) that lead to various interpretations (Morelli, 2013).

Firms, as the productive resources of the economies, have significant impact on the sustainable development and sustainability. Consequently the operationalization of the terms and concepts in the business context soon received immediate attention giving rise to the sustainability reporting of the triple bottom line (TBL) (Barkemeyer et al., 2014). TBL is used interchangeably with sustainability (Alhaddi, 2015).From the business perspective it means the strategies and activities to achieve the three integrated goals of economic, environmental and social dimensions (Harmon, Fairfield, \& Behson, 2009; Slaper \& Hall, 2011). These activities are termed the triple bottom line of 3Ps - profit, planet and people. The accounting framework of Triple Bottom line, a term, according to Montabon, Pagell \& Wu, (2016), was coined by Elkington in 1994, is the dominant concept in sustainability literature that encourages a more balanced reporting of overall business performances on the 3Ps. The concept is more than just accounting and reporting in the corporate reports, but include in the business decision the assessment of the risks, obligations and opportunities of all financial, social and environmental fronts. In fact the triple bottom of social, economic and environmental factors was aptly described in the definition of sustainable development by United Nation's 1989 Brundtland Commission. Besides the three dimensions, sustainability in business has also been linked to corporate social responsibility (CSR) (Kopnina, 2015), ethical concern (John \& Narayanamurthy, 2015), and the element of time (Lozano, Carpenter \& Huising, 2015).

Nonetheless, how to accomplish it is hard to understand. TBL is not short of criticisms particularly its measurement approach and integration of the three dimensions of profit, people and planet factors (Sridhar \& Jones, 2013; Rambaud \& Richard, 2015). The road to achieve the unknown goals and benefits, the directions and strategies to be taken, and the trade-off between cost or economic elements and protecting the environment by reducing the carbon foot print and fostering social responsibility remain elusive (Miller, 2010; Mohrman \& Worley, 2010). Montabon et al. (2016) mention that the current sustainability logic of the trade-off between reducing environmental harm and social survival while achieving increasing profit will not lead to true sustainability.

From the business perspective, sustainable development can be defined as collective strategies and activities undertaken by the firms to achieve the current objectives of its stakeholders while assuring the needs of future generations (Bansal \& DesJardine, 2015). It means integrating the dimensions of triple bottom line of economic, environmental and social in their plans and achieving all three goals at the same time (Goodman, 2001; Harmon et al., 2009; Sartori et al., 2014). In other words, it means responsible use of resources to generate profit (Danciu, 2013). As the result sustainability has been used to describe both the process (for example sustainable business, and others), and the activities that are aimed to be sustainable, in the likes of sustainable agriculture and others (Santori et al., 2014).

The above discussion illustrates the concept and usage of sustainability over various subject matters such as "sustainable education", "sustainable university", "sustainable building", "sustainable procurement", "sustainable operation", "sustainable company", "sustainable entrepreneur", "sustainable entrepreneurship" "sustainable growth", "sustainable knowledge" and other usages. This phenomenon has created confusion and abuse of the meaning of the phrase leading to different objectives, warranting immediate scholarly attention to clarify and delineate the objectives of sustainable growth in emerging contexts. Unified definitions of sustainable growth needs to be brought forward explaining the concept that should not be able to and describe sustainable growth but also set its perimeter right and in order to avoid any ambiguity that might arise while interpreting the concept.

\subsection{Defining Sustainable Growth}

The term sustainable growth has also been defined variedly by various studies. From the financial standpoint, sustainable growth denotes growth within the firm's financial constraints (Huang \& Liu, 2009; Alayemi \& Akintoye, 2015) without increasing its financial leverage (Ross, Westerfield, \& Jordan, 2010). Harmon et al. (2009) define it as the ability of the firm to achieve its objectives and shareholders' value through a concerted effort to integrate economic, environmental, and social activities into its strategies. Nonetheless not all SMEs are able to achieve all the three factors or even have at their disposals necessary resources to incorporate the three elements of sustainable as their mission and objectives (Goswami \& Ha-Brookshire, 2015). Guoli and Shujun (2011) define sustainable growth as affordable growth. Stefanikova, Rypakova, and Moravcikov (2015) define sustainable growth as long term perspective of growth. This line of definition is also being used by Mogos, Davis and Baptista (2015) who define sustainable growth as achieving long term growth with low downside. 
According to Ali, Ismail, Khurram, Soehod, and Omar (2014), Jafri, Ismail, Khurram and Soehod, (2014), and Ismail, Jafri, Khurram, and Soehod, (2012), sustainable growth has been defined in their studies as achieving growth without having financial, structural or strategic setbacks.Schwab, Gold, Kunz, and Reiner (2017) add to the list by defining sustainable growth as growth in economic, social and environmental performance.

Doane and MacGillivray (2001) view sustainability as long-term survival from all the three aspects of environmental, social and economic. Hence all the three objectives of the three pillars of sustainability should complement each other (Gomez-Bezares, Przychodzen, \& Przychodzen, 2014). The word sustainable has also been generally perceived as able to 'maintain' or 'continue to last', endlessly increasing or ongoing with time frame referring to long, future and indefinitely (Markulev \& Long, 2013; Owens \& Legere, 2015; Kopnina, 2015). Meng (2015) further adds that sustainability involves continuous growth of both dimensions of, firstly, the dimension of time, through maximizing current benefits while permitting future growth, and secondly, the dimension of place, through increasing distributive justice in human society.

Following the above perspective of continuous growth, this study conceptualizes sustainable growth of SMEs as self-sufficiency growth by achieving financial objectives and performance that is continuous over time within the firms' capabilities while affirming and sustaining future objectives without jeopardizing their long term survival. Put it differently, the sustainable growth in this study is conceptualized following the conventional economist perspective as growth within the firm's ability to support such growth as the continuous state of growth that is manageable, maintainable, and affordable (Seens, 2013) within the firm's ability and capabilities (Huang \& Liu, 2009) to support such growth by achieving financial performance through environmental strategies such as improvement and effective consumption of energy and raw material, waste reduction activities, and through the social strategies such as promoting employee satisfaction and retention. However this study departs from the normal concept of conventional economic sustainability by not only being able to stay in business (Doane \& MacGillivray, 2001) economically, but at the same achieving the other objectives of environment and social measured in economic terms of the business. This definition falls under the ambit of economic sustainability that refers to ability of the firms to survive to meet the current objectives of the stakeholders without compromising with the future existences and objectives (Found \& Rich, 2006). In this perspective, sustainability refers to a steady state and efficiency (Lozano, 2008).

From the perspective of long term survival and maintainable or sustainable growth, the profit factor is an important element (Stancu, Stancu, Dumitrescu, \& Tinca, 2015).Firm's growth has been found to be related to profitability (Yazdanfar \& Ohman, 2015; Kachlami \& Yazdanfar, 2016), and firm's profitability is influenced by its productivity (Yazdanfar, 2013). Firm sustainable growth is expected to overcome the liability of smallness (Wolff, Pett \& Ring, 2015, p. 6) that can better withstand the challenging business environment.

The profitability objective will influence the firm's strategic moves to increase its return through programs that will reduce wastages, reusing and recycling its scares resources to achieve economic gains, which is in fact one of the environmental objectives (Maletic, Maletic, Dahlgaard, Dahlgaard-Park, \& Gomiscek, 2015). The firms' performance and growth would enable the firm to achieve long term survival to create continuous employment opportunities. The firms would also have to enhance its human capital through retraining, retention and employee satisfaction. These form the social objectives (Maletic et al., 2015) under sustainability studies. Having employee commitment and skills development is one of the ingredients for successful firms. The social welfare of the employees in terms of safe working place that remove occupational hazard would motivate long term commitment of the employees. Monetary and non-monetary benefits will ensure long term employment. This is the social goals of the firm, which is, indirectly removing poverty. Ratiu and Anderson (2015) found that majority of firms in their study focus on these activities in their sustainability plans. Hence in this study sustainable growth refers to the continuous and maintainable growth of the firms from the economic perspective representing the performances from the financial, quality, environment, and social aspects of SMEs. This approach is in line with the view of John and Narayanamurthy (2015) that economic perspectives of sustainable growth focus on optimum planning for the effective utilization of resources such as recycling or raw materials, waste reduction and waste management and are the most attractive avenue for sustainable growth for the practitioner.

\subsection{Sustainable Growth and SMEs}

The discussions on the contribution of SMEs to the economic contribution in the previous sections emphasize the needs of not only the formation of new SMEs and survival of all SMEs in the economy, but more importantly to ensure that they sustain their growth (Wakkee, Van Der Veen, \& Eurlings, 2015).One of the challenges of SMEs is to be sustainable, become sustainable and more importantto remain sustainable (Gunilla, 2014), or else failure will 
inevitably take center stage. Many SME companies had failed on the journey with many reasons put forth to justify their failures (Rahman, Yaacob, \& Radzi, 2016).

Sustainable growth of SMEs indicates entrepreneurial activities that are healthy in the economy (Ismail, Jafri et al, 2012). It is also a prominent indicator of success for SMEs (Salojarvi, Furu, \& Sveiby, 2005), and prosperity of the society. Literature review reveals many benefits and importance of sustainable growth (Gomez-Bezares et al., 2014), few of which are; a) sustainable growth is important to ensure the ability of the firm to finance its long term future development (Chang, 2012) and for its long term survival (Huang \& Liu, 2009); b) sustainable growth of SMEs is crucial for long term development of national economies (Mazzarol \& Reboud, 2006); c) higher return through cost reduction from the efficient utilization of material and energy (Epstein \& Buhovac, 2014); e) high productivity through high employee retention rate and pool of skilled workers (Perrott, 2015); f) controlled and manageable firm growth (Perrott, 2015).

These benefits warrant studies from various perspectives on sustainable growth. It has been acknowledged that the inability of SMEs to remain in business with high failure rate have attracted many interest to study the factors that may lead to sustainable growth of SMEs in developing countries (Asa \& Prasad, 2014). From the various theoretical perspectives, models and frameworks to empirically test the wide range of variables have been developed.It is anticipated those sustainable companies that are connected healthily with the eco-system can survive on long term basis (Bertels, Papania, \& Papania, 2010). In the study by Gomez-Bezares et al. (2014) using 65 companies listed in FTSE 350 index of the London Stock Exchange (LSE) as the sample, found that companies that practice well balanced financial, environmental and social investments in their strategies produce long term increase in shareholders' wealth and corporate value.

\subsection{Future Perspective on Sustainable Growth of SMEs}

While there are many factors affecting growth of firm, knowledge about whether they would influence firm growth permanently over time is rare and unclear (Schimke \& Brenner, 2011). This has been established by Schimke and Brenner (2011) in their study using a panel-data on 178 German small and medium sized manufacturing firms for a period from 1992 to 2007, found that the factors affecting firms' continuous growth and firms' growth at one point in time are different. Few attempts to conceptualize certain specific factors affecting long-term or sustainable growth have also been proposed in various models such as the four factors of learning, culture, relationship and management (Geus, 1997), durability, autonomy and profitability (Bivona, 2000), entrepreneurs' characteristics, innovation, strategic networking, and strategies (Mazzarol \& Reboud, 2006), the psychological traits (Ali et al., 2014), capital structure (Rahim \& Saad, 2014), and resources, innovative capability, culture, system and strategy (Khan, 2015). Few other studies include relationship between sustainable growth and entrepreneur's profile (Berry \& Taggart, 1998), integration of skills with resources (Teixeira \& Fortuna, 2004), innovative capability (Ismail, Rose, Uli, \& Abdullah, 2012), management team (Kraemer, 2004), management practices (Fuller, Warren, \& Argyle, 2008), growth strategy and growth capability (Amouzesh et al., 2011), business quality management (Tarek, 2011), knowledge strategy and business model (Yun, Jung, \& Yang, 2015) and the entrepreneur's intention to grow (Berry \& Taggart, 1998; Ismail et al., 2012).

Knowledge on continuous growth or growth over longer period of time is limited (Achtenhagen, Naldi, \& Melin, 2010). Research on sustainable growth has been focused on large companies listed in Iran Financial Market (Amouzesh et al., 2011), Asean Bourses (Rahim \& Saad, 2014), London Stock Exchange (Gomez-Bezares et al., 2014), Chinese GEM (Huang \& Zhang, 2015), Bucharest Stock Market (Stancu et al., 2015) and Bursa Saham, Malaysia (Rahim, 2017). While many factors have been studied from different perspectives to predict the growth of the firm, it still remains unclear to explain and predict the sustainability growth of SMEs. A consensus on the most appropriate model of sustainable growth of SMEs is no near to be achieved. Hence the pressing need for a sustainable growth model of SMEs is obvious. The search for a model that focuses on the question of 'how' and not just 'how much', and encompassing all impactful intangible factors within the firms forming the foundations of strategic activities that will eventually lead them to sustainable growth enterprises. The complexity and interconnectedness of the three pillar nexus of three relationships of people, planet and profit require new operating logics (Mohrman \& Worley, 2010) that are beyond any robust existing framework and models.

To promote reliable, long lasting existence and continuous growth of the firm, it is imperative to identify the factors that both hinder and stimulate firm sustainable growth. However it requires more than just acknowledging the optimum combination of such factors, but it should be able to formulate their accumulation, bundling and leveraging of those resources and capabilities to generate sustainable growth (Fraser, Bhaumik, \& Wright, 2015). Regrettably sustained growth is uncommon with majority of the firms are not growing (Dobbs \& Hamilton, 2007). Furthermore maintainable or sustainable growth has not been given much attention in past research and no attempt 
to discuss whether growth is temporary or continuous. Except for the various mathematical model to determine the firm's maximum or sustainable rate of growth, there is still lack of knowledge on the prerequisite for sustainable growth model (Industry Canada, 2014).

It is proposed in this study that the factors to determine the sustainable growth of SMEs should not only be limited to a single or a few major intangible factors as noted by Kamasak (2014), but more importantly the intangible factors should encompass the three levels of the domain of SMEs (Warren, 2004) covering the entrepreneurs, the enterprises, and the relationships with the eco-systems and external environments of SMEs.It has been found that intangible resources and capabilities are important towards contributing to sustainable growth (Wakkee, Van Der Veen, \& Eurlings, 2015) and recent research have shown positive and significant influence on competitive advantage (Thum-Thysen, Voigt, Bibao-Osario, Maier, \& Ognyanova, 2017), and on growth (Reid, Smith \& Xu, 2017). Orser et al. (1998) found in their research that future actual growth of the firm is influenced by the growth intention of the entrepreneurs. Generally, growth of the firms depends on the mindset of the entrepreneurs, which is their vision, attitude and perception (Lebrasseur et al., 2006). Bulanova, Isaksen, and Kolvereid, (2016) suggest that growth willingness or aspiration is influenced by the entrepreneurs' attitude towards growth or perceived desirability and the feasibility of business growth or self-efficacy. There are various factors that influence the evolution of the entrepreneurs' growth intention, depending on the way they perceive and interpret barriers (Doern, 2011). These beliefs that affect their attitudes towards growth, the perceived expectation of the others, and the ability to perform the behaviour form the three dimensions of the TPB (Ajzen, 2002; Ajzen \& Dasgupta, 2015). The study by Bulanova et al. (2016) confirms that the key predictor of actual firm growth is growth aspiration.

The proposed integrated framework of sustainable growth of SMEs is illustrated in Figure 1 where the factors within the domain of SMEs will have significant effect on the dimensions of economic perspective of sustainable growth.

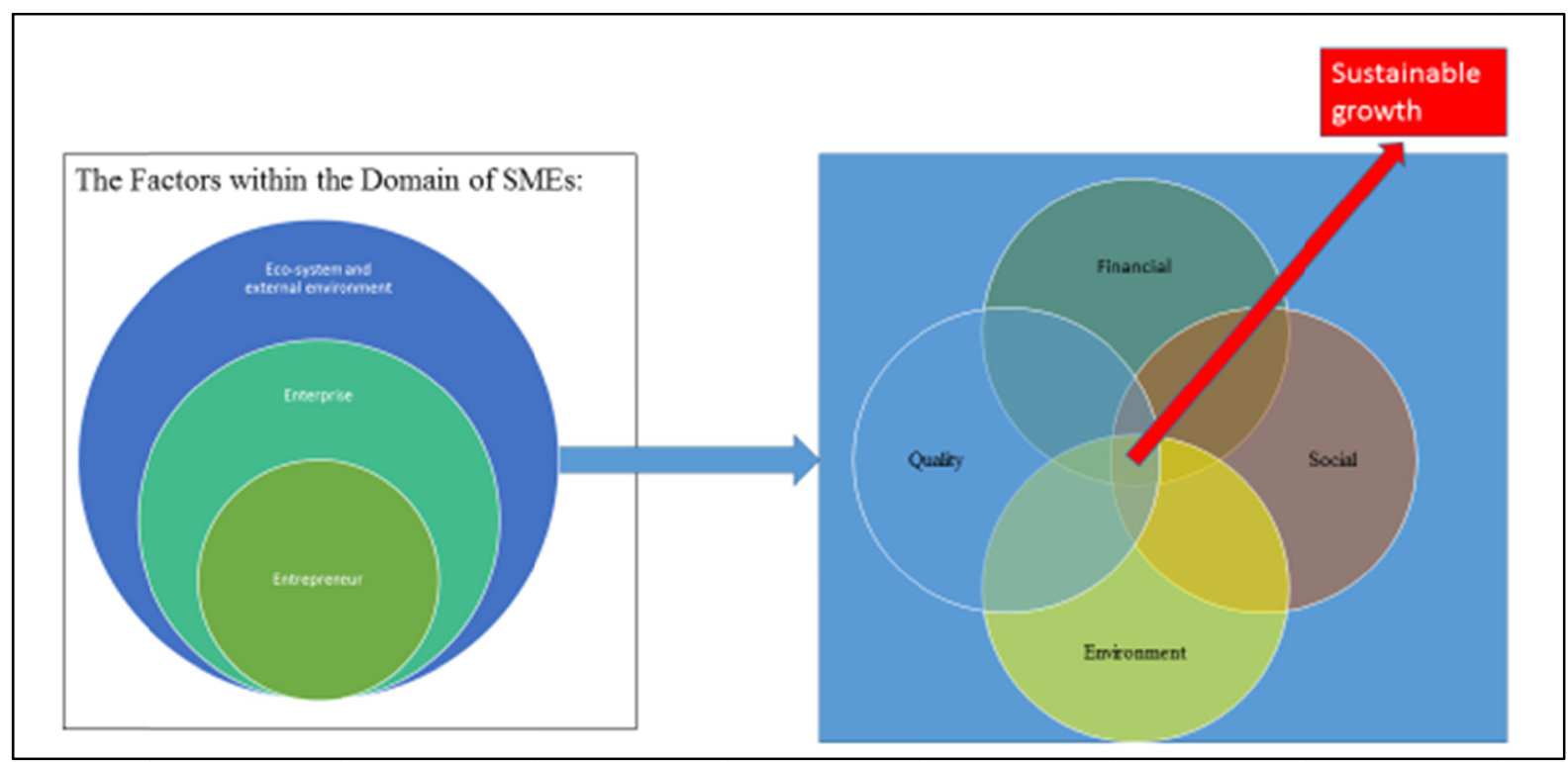

Figure 1. Proposed integrated framework of sustainable growth of SMEs

\section{Conclusion}

The low contribution to the GDP should be of concern to all interested parties. Many reasons can be indicated including the personal level issues regarding the entrepreneurs' attitude, motivation and competencies, to firm level problems related to strategies and innovations, and to the macro level of external business climatic conditions. The never fading support from the government would be made more fruitful by focusing on the development of specific areas being presented in this study to assist and provide timely, adequate and objective support to SMEs to achieve sustainable growth as suggested by Ahmedova (2015, p. 1112). Besides filling the gap of nonexistence of a sustainable growth framework for SMEs in Malaysia, this study would give unprecedented directions for the policy makers in their quest to achieve the nation's objective through the development and growth of SME sector. 
Evidently, this paper reveals that the attention towards achieving sustainable growth of SMEs has not been given due consideration to assist the practitioners and policy makers alike to equip with relevant strategies and plans to sustain the growth of the SMEs. It is envisaged this review can be the basis for future research to develop an integrated model of sustainable growth of SMEs focusing on the internal intangible factors of the enterprises that can give a clear understanding of the determinants to achieve sustainable growth and to enhance the effective design and utilization of the government support programs. As a concluding remark, based on the discussions above, this paper proposes the introduction of the term "sustagrowprises" that refers to sustainable growth enterprises. It is used interchangeably with firm sustainable growth, sustainable growth of the firm, or sustainable growth of SMEs. The term "sustagrowprises" shall denote sustainable growth of SMEs over a long period of time with maintainable and sustainable profitability through effective energy and raw material consumption, and other waste reduction programs while achieving employee satisfaction and motivation

\section{References}

Abdullah, N., \& Rosli, N. F. (2015). An Evaluation on Determinants of Smes Performance in Malaysia. South East Asia Journal of Contemporary Business, Economics and Law, 7(2), 16-23. Retrieved from http://seajbel.com/wp-content/uploads/2015/09/KLIBEL7_Bus-16.pdf

Ahmad, N. H., \& Seet, P. S. (2009). Dissecting behaviours associated with business failure: A qualitative study of SME owners in Malaysia and Australia. Asian Social Science, 5(9), 98-104. https://doi.org/10.5539/ass.v5n9p98

Ahmedova, S. (2015). Factors for Increasing the Competitiveness of Small and MediumSized Enterprises (SMEs) In Bulgaria. Procedia-Social and Behavioral Sciences, 195, 1104-1112. https://doi.org/10.1016/j.sbspro.2015.06.155

Ajzen, I., \& Dasgupta, N. (2015). Explicit and Implicit Beliefs, Attitudes, and Intentions: The role of conscious and unconscious processes in Human Behavior. In P. Haggard \& B. Eitam (Eds.), The Sense of Agency (pp. 115-144). New York: Oxford University Press. https://doi.org/10.1093/acprof:oso/9780190267278.003.0005

Alayemi, S. A., \& Akintoye, R. I. (2015). Strategic Management of Growth in Manufacturing Companies in Sub-Saharan Africa: A Case Study of Nigeria. British Journal of Economics, Management \& Trade, 6(2), 151-160. https://doi.org/10.9734/BJEMT/2015/13796

Alhaddi, H. (2015). Triple bottom line and sustainability: a literature review. Business and Management Studies, 1(2), 6-10. https://doi.org/10.11114/bms.vli2.752

Ali, S. K., Ismail, K., Khurram, W., Soehod, K. B., \& Omar, W. Z. W. (2014). Sustainable Growth of Women Owned Technoprises in Malaysia. Research Journal of Applied Sciences, Engineering and Technology, 7(17), 3582-3592. https://doi.org/10.19026/rjaset.7.711

Asa, A. R., \& Prasad, N. S. (2014). Analysis on the Factors that Determine Sustainable Growth of Small Firms in Namibia. International Journal of Management Science and Business Administration, 1(1), 5-11. https://doi.org/10.18775/ijmsba.1849-5664-5419.2014.11.1001

Bansal, P., \& DesJardine, M. R. (2014). Business sustainability: It is about time. Strategic Organization, 12(1), 70-78. https://doi.org/10.1177/1476127013520265

Barkemeyer, R., Holt, D., Preuss, L., \& Tsang, S. (2014). What happened to the 'development' in sustainable development? Business guidelines two decades after Brundtland. Sustainable development, 22(1), 15-32. https://doi.org/10.1002/sd.521

Bernama. (2017, September 8). Press release: AmBank launches entrepreneurship challenge 'AMBANK BIZRACE'. Bernama MREM. Retrieved from http://mrem.bernama.com/viewsm.php?idm=29994

Bertels, S., Papania, L., \& Papania, D. (2010). Embedding sustainability in organizational culture. A systematic review of the body of knowledge. London, Canada: Network for Business Sustainability. Retrieved from http://nbs.net/wp-content/uploads/Systematic-Review-Sustainability-and-Corporate-Culture.pdf.

Borim-de-Souza, R., Balbinot, Z., Travis, E. F., Munck, L., \& Takahashi, A. R. W. (2015). Sustainable development and sustainability as study objects for comparative management theory: proposing styles of reasoning for an unknown metropole. Cross Cultural Management, 22(2), 201-235. https://doi.org/10.1108/CCM-02-2013-0027

Bulanova, O., Isaksen, E. J., \& Kolvereid, L. (2016). Growth aspirations among women entrepreneurs in high growth firms. Baltic Journal of Management, 11(2), 187-206. https://doi.org/10.1108/BJM-11-2014-0204 
Bureau of Labor Statistics. (November 2017). Survival rates of establishments, by year started and number of years since starting, 1994-2015. Retrieved from https://data.bls.gov/cgi-bin/print.pl/bdm/entrepreneurship/bdm_chart3.htm

Chang, Y. C. (2012). Strategy formulation implications from using a sustainable growth model. Journal of Air Transport Management, 20, 1-3. https://doi.org/10.1016/j.jairtraman.2011.03.010

Chong, W. Y. (2012). Critical success factors for small and medium enterprises: Perceptions of entrepreneurs in urban Malaysia. Journal of Business and Policy Research, 7(4), 204-215. Retrieved from $\mathrm{http}: / /$ wbiaus.org/14.\%20Wei.pdf

Danciu, V. (2013). The sustainable company: new challenges and strategies for more sustainability. Theoretical and Applied Economics, 18(9), 7-26. Retrieved from http://store.ectap.ro/articole/898.pdf

De Geest, D. S., Follmer, E. H., Walter, S. L., \& O’Boyle, E. H. (2015). The Benefits of Benefits: A Dynamic Approach to Motivation-Enhancing Human Resource Practices and Entrepreneurial Survival. Journal of Management, $X X(\mathrm{X}), 1-30$.

De Kok, J., Zhou, H., Van der Zwan, P., \& Hartog, C. (2014). Is there a risk of growing fast? A study of the relationship between firm growth and firm exit. Scientific Analysis of Entrepreneurship and SMEs. Retrieved from

http://www.entrepreneurship-sme.eu/sys/cftags/assetnow/design/widgets/site/ctm_getFile.cfm?file=H20141 3.pdf\&perId $=0$

Department of Statistics. (2017). Press Release, Small and Medium Enterprises Gross Domestic Products (SMEs GDP) $2016 . \quad$ Retrieved from https://www.dosm.gov.my/v1/index.php?r=column/pdfPrev\&id=YzI2NWE2U0tXS1VEdnFsWHpqM1Fud z09

Doane, D., \& Macgillivray, A. (2001). Economic Sustainability: The business of staying in business. London: The SIGMA Project. Retrieved from http://www.projectsigma.co.uk/RnDStreams/RD_economic_sustain.pdf

Dobbs, M., \& Hamilton, R. T. (2007). Small business growth: recent evidence and new directions. International Journal of Entrepreneurial Behavior\& Research, 13(5), 296-322. https://doi.org/10.1108/13552550710780885

Dreyer, J., Erasmus, P., Morrison, J., \& Hamman, W. (2013). Sustainable company growth as measured by cash flow. Management Dynamics: Journal of the Southern African Institute for Management Scientists, 22(2), 16-28.

http://search.proquest.com.eserv.uum.edu.my/business/docview/1439534586/fulltextPDF/7DD0ECB7239B $4 \mathrm{~A} 2 \mathrm{EPQ} / 2$ ?accountid $=42599$

Epstein, M. J., \& Buhovac, A. R. (2014). Making Sustainability Work: Best Practices in Managing and Measuring Corporate Social, Environmental, and Economic Impacts (2nd ed.). United Kingdom. Retrieved from http://www.bkconnection.com/static/Making_Sustainability_Work_2nd_EXCERPT.pdf

Found, P., \& Rich, N. (2006). Making it all 'Add Up’: A Systems Approach to Economic Sustainability. Cardiff. Cardiff Business School. Retrieved http://isites.harvard.edu/fs/docs/icb.topic259001.files/MakingitallAddUpASystemsApproachtoEconomicSu stainability.pdf

Fraser, S., Bhaumik, S. K., \& Wright, M. (2015). What do we know about entrepreneurial finance and its relationship with growth? International Small Business Journal, 33(1), 70-88. https://doi.org/10.1177/0266242614547827

Galpin, T., \& Hebard, J. (2015). Sustainability in start-up ventures: what founders say versus what they do. World Journal of Entrepreneurship, Management and Sustainable Development, 11(4), 246-255. $\mathrm{http} / / / \mathrm{dx}$.doi.org/10.1108/WJEMSD-05-2015-0025

Gomez-Bezares, F., Przychodzen, J., \&Przychodzen, W. (2014). Corporate Sustainability and Shareholder Wealth - Evidence from British Companies and Lessons from the Crisis. Received from: http://22financeforum.unizar.es/wp-content/uploads/2014/11/22financeforum_submission_22_Corporate-S ustainability.pdf

Goodman, M. B. (2001). Symposium on Sustainability: Profiles in Leadership. Corporate Communication Institute. Retrieved from http://www.corporatecomm.org/pdf/1001_welcome.pdf 
Goswami, S., \& Ha-Brookshire, J. (2015). From compliance to a growth strategy. Journal of Global Responsibility, 6(2), 246-261. http://dx.doi.org/10.1108/JGR-04-2015-0005

Gunilla, A. (2014). Sustainability and SMEs: The Next Steps. In C. Weidinger et al. (Eds.), Sustainable Entrepreneurship, CSR, Sustainability, Ethics \& Governance. https://doi.org/10.1007/978-3-642-38753-1_20

Guoli, Y., \& Shujun, Y. (2011). The Comparative Analysis of Sustainable Growth Pattern. M \& D Forum. 2011. Retrieved from http://www.seiofbluemountain.com/upload/product/201111/2011kjxic2.pdf

Habidin, N. F., Zubir, A. F. M., Fuzi, N. M., Latip, N. A. M., \& Azman, M. N. A. (2015). Sustainable manufacturing practices in Malaysian automotive industry: confirmatory factor analysis. Journal of Global Entrepreneurship Research, 5(1), 14. https://doi.org/10.1186/s40497-015-0033-8

Harmon, J., Fairfield, K. D., \& Behson, S. (2009). A Comparative Analysis of Organizational Sustainability Strategy: Antecedents and Performance Outcomes Perceived by U. S. and Non-U.S.-Based Managers. Presented at the International Eastern Academy of Management Conference Rio de Janiero, Brazil, June 2009. Retrieved from http://view.fdu.edu/files/rschpprorgsusbrazil09.pdf

Huang, R., \& Liu, G. (2009). Study on the enterprise sustainable growth and the leverage mechanism. International journal of Business and Management, 4(3), 200-205. https://doi.org/10.5539/ijbm.v4n3p200

Industry Canada. (2014). Growth or Profitability First? The Case of Small and Medium-Sized Enterprises in Canada. $\quad$ Retrieved https://www.ic.gc.ca/eic/site/061.nsf/vwapj/GP-CR_2014-10_eng.pdf/\$file/GP-CR_2014-10_eng.pdf

Isada, F., \& Isada, Y. (2015). An Empirical Study about Sustainable Growth and Organization Innovation of a Multinational Firm in an Emerging Country. Journal of Economics, Business and Management, 3(3), 383-390.

Ismail, A. I., Rose, R. C., Uli, J., \& Abdullah, H. (2012). The Relationship between Organisational Resources, Capabilities, Systems and Competitive Advantage. Asian Academy of Management Journal, 17(1), 151-173. Retrieved from http://web.usm.my/aamj/17.1.2012/AAMJ_17.1.8.pdf

Ismail, K., Jafri, K. A., Khurram, W., \&Soehod, K. (2012). Linking the Dots: Innovative Capability and Sustainable Growth of Women Owned Technoprises in Asian Developing Countries. International Journal of Academic Research in Business and Social Sciences, 2(4), 281. Retrieved from http://www.hrmars.com/admin/pics/718.pdf

Jabareen, Y. (2008). A new conceptual framework for sustainable development. Environment, Development and Sustainability, 10(2), 179-192. https://doi.org/10.1007/s10668-006-9058-z

Jafri, S. K. A., Ismail, K., Khurram, W., \& Soehod, K. (2014). Impact of Social Capital and Firms' Innovative Capability on Sustainable Growth of Women Owned Technoprises (SMEs): A Study in Malaysia. World applied sciences journal, 29(10), 1282-1290.

Jebna, A. K. K., \& Baharudin, A. S. (2013). Factors affecting small and medium enterprises success: An Exploratory study. SainsHumanika, 64(3), 69-72. https://doi.org/10.11113/jt.v64.2272

John, L., \& Narayanamurthy, G. (2015). Converging sustainability definitions: industry independent dimensions. World Journal of Science, Technology and Sustainable Development, 12(3), 206-232.

Kachlami, H., \& Yazdanfar, D. (2016). Determinants of SME Growth: The Influence of financing pattern An empirical study based on Swedish data. Management Research Review, 39(9), http://dx.doi.org/10.1108/MRR-04-2015-0093.

Kamasak, R. (2014). Another Attempt to look inside the "Black Box" of Performance Creation: A Case Study Approach. International Journal of Business and Social Research (IJBSR), 4(7). Retrieved from http://ijbssnet.com/journals/Vol_6_No_3_March_2015/14.pdf

Kee-Luen, W., Thiam-Yong, K., \& Seng-Fook, O. (2013). Strategic Planning and Business Performance: A Study of SMEs in Malaysia. Proceedings of 3rd Asia-Pacific Business Research Conference 25 - 26 February 2013, Kuala Lumpur, Malaysia, Retrieved from http://economics.mit.edu/files/521

Khan, M. M. S. (2015). The longevity of large enterprises: a study of the factors that sustain enterprises over an extended period of time. The Journal of Developing Areas, 49(5), 41-52. https://doi.org/10.1353/jda.2015.0071 
Khan, M. W. J., \& Khalique, M. (2014). A Holistic Review of Empirical Studies of Strategic Planning and Future Research Avenues. International Journal of Academic Research in Economics and Management Sciences, 3(6). https://doi.org/10.6007/IJAREMS/v3-i6/1291

Kopnina, H. (2017). Sustainability: new strategic thinking for business. Environment, Development and Sustainability, 19(1), 27-43. https://doi.org/10.1007/s10668-015-9723-1

Lang, A., \& Murphy, H. (2014). Business and Sustainability: An Introduction. In A. Lang \& H. Murphy (Eds.), Business and Sustainability. Sustainability and Innovation. Springer, Cham. https://doi.org/10.1007/978-3-319-07239-5_1

Lozano, R. (2008). Envisioning sustainability three-dimensionally. Journal of Cleaner Production, 16(17), 1838-1846. https://doi.org/10.1016/j.jclepro.2008.02.008

Lozano, R., Carpenter, A., \&Huisingh, D. (2015). A review of 'theories of the firm'and their contributions to Corporate Sustainability. Journal of Cleaner Production, 106, 430-442. http://dx.doi.org/10.1016/j.jclepro.2014.05.007.

Madanchian, M., Hussein, N., Noordin, F., \& Taherdoost, H. (2015). The Role of SMEs in Economic Development: Case Study of Malaysia. International Journal of Academic Research in Management, 4(3), 77-84. Retrieved from: http://elvedit.com/journals/IJARM/wp-content/uploads/2015/12/The-Role-of-SMEs-in-Economic-Develop ment-Case-Study-of-Malaysia1.pdf

Maletic, M., Maletic, D., Dahlgaard, J., Dahlgaard-Park, S. M., \& Gomišcek, B. (2015). Do corporate sustainability practices enhance organizational economic performance? International Journal of Quality and Service Sciences, 7(2/3), 184-200. http://dx.doi.org/10.1108/IJQSS-02-2015-0025

Markulev, A., \& Long, A. (2013). On sustainability: an economic approach, Staff Research Note, Productivity Commission, $2013 . \quad$ May Canberra. Retrieved from http://www.uws.edu.au/_data/assets/pdf_file/0008/473327/Economic_sustainability_discussion_paper_Ma y_2013.pdf

Mazzarol, T., \& Reboud, S. (2006). Strategic Management in Small Firms: Developing a Conceptual Framework. Paper presented at the 20th Annual Australia \& New Zeland Academy of Management (ANZAM) Conference 2006, Rockhampton. 6-10 December. Retrieved from http://www.cemi.com.au/sites/all/publications/ANZAM\%20MAZZREB06.pdf

Meng, J. (2015). Sustainability: a framework of typology based on efficiency and effectiveness. Journal of Macromarketing, 35(1), 84-98. https://doi.org/10.1177/0276146714541128

Miller, J. L. (2010). Sustainability: Is It a Good Choice for Small Companies? Inquiries Journal, 2(10). Retrieved from: http://www.studentpulse.com/a?id=295

Mogos, S., Davis, A., \& Baptista, R. (2015). Defining High Growth Firms: Sustainable Growth, Volatility, and Survival. Paper presented at DRUID15, Rome, June 15-17, 2015. Retrieved from http://druid8.sit.aau.dk/acc_papers/rpq1k6cpebbhti9vh29xudqp3juy.pdf

Mohrman, S. A., \& Worley, C. G. (2010). The Organizational Sustainability Journey: Introduction to the Special Issue. Organizational Dynamics, 39(4). https://doi.org/10.1016/j.orgdyn.2010.07.008

Montabon, F., Pagell, M., \& Wu, Z. (2016). Making sustainability sustainable. Journal of Supply Chain Management, 52(2), 11-27. https://doi.org/10.1111/jscm.12103

Morelli, J. (2011). Environmental sustainability: A definition for environmental professionals. Journal of environmental sustainability, 1(1), Article 2.

Musa, H., \& Chinniah, M. (2016). Malaysian SMEs Development: Future and Challenges on Going Green. Procedia-Social and Behavioral Sciences, 224, 254-262. https://doi.org/10.1016/j.sbspro.2016.05.457

National Economic Advisor Council (NEAC). (2009). New Economic Model for Malaysia, Part 1: Strategic Policy Direction. National Economic Advisory Council. 30 March 2009. Retrieved from http://www.epu.gov.my/epu-theme/pdf/nem.pdf

NSDC (2017). SME Annual Report 2016/2017. September 2017. Retrieved from http://www.smecorp.gov.my/index.php/en/laporan-tahunan/2150-sme-annual-report-2016-17

NSDC. (2012). Summary SME masterplan 2012-2020. Retrieved from 
http://www.smecorp.gov.my/vn2/sites/default/files/SME\%20Masterplan\%202012-2020\%20(booklet)_0_0. pdf

NSDC. (2014). SME Annual Report 2013/2014. September 2014. Retrieved from:http://www.smecorp.gov.my/vn2/node/1475

Ong, J. W. (2015). Evaluating the Sustainable Practices of SME Master Plan and Recommendations for Improvement. International Academic Research Journal of Social Science, 1(2), 240-247. Retrieved from http://www.iarjournal.com/wp-content/uploads/33-P240-247.pdf

Owens, K. A., \& Legere, S. (2015). What do we say when we talk about sustainability? Analyzing faculty, staff and student definitions of sustainability at one American university. International Journal of Sustainability in Higher Education, 16(3), 367-384. http://dx.doi.org/10.1108/IJSHE-06-2013-0055

Perrott, B. E. (2015). Building the sustainable organization: an integrated approach. Journal of Business Strategy, 36(1), 41-51. http://dx.doi.org/10.1108/JBS-06-2013-0047

Prabawani, B. (2013). Measuring SME's Sustainability: A Literature Review and Agenda for Research. International Journal of Management and Sustainability, 2(12), 193-207. Retrieved from http://www.pakinsight.com/pdf-files/ijms\%202(12),\%20193-207.pdf

Rahim, N. (2017). Sustainable growth rate and firm performance: A case study in Malaysia. International Journal of Management, Innovation \& Entrepreneurial Research, 3(2), 48-60. https://doi.org/10.18510/ijmier.2017.321.

Rahim, N., \& Saad, N. (2014). Sustainable Growth of Public Listed Companies (PLC) Using Capital Structure Choices and Firm Performance in an ASEAN Market. Proceeding of the Global Summit on Education GSE 2014. 4-5 March 2014, Kuala Lumpur, Malaysia. Retrieved from WorldConferences.net. http://worldconferences.net/proceedings/gse2014/toc/papers_gse2014/G\%20153\%20-\%20NORFHADZILA HWATI_SUSTAINABLE\%20GROWTH\%20OF\%20PUBLIC\%20LISTED\%20COMPANIES\%20(PLC) \%20USING\%20CAPITAL\%20STRUCTURE\%20CHOICES\%20AND\%20FIRM\%20PERFORMANCE\% 20IN\%20AN\%20ASEAN\%20MARKET_read.pdf

Rahman, N. A., Yaacob, Z., \& Radzi, R. M. (2016). The challenges among Malaysian SME: ATheoretical perspective. World Journal of Social Sciences, 6(3), 124-132. Retrieved from http://www.wjsspapers.com/static/documents/September/2016/10.\%20Nurulhasnah.pdf

Rambaud, A., \& Richard, J. (2015). The "Triple Depreciation Line" instead of the "Triple Bottom Line": towards a genuine integrated reporting. Critical Perspectives on Accounting, 33, 92-116. http://dx.doi.org/10.1016/j.cpa.2015.01.012

Ratiu, C., \& Anderson, B. B. (2015). The multiple identities of sustainability. World Journal of Science, $\begin{array}{llll}\text { Technology and } & \text { Sustainable }\end{array}$ http://dx.doi.org/10.1108/WJSTSD-05-2015-0022.

Reid, G., Smith, J., \& Xu, Z. (2017) Intangible assets and determinants of firm growth in China. In British Accounting \& Finance Association (BAFA) Annual Conference 2017, 10-12 April 2017. Heriot Watt University. Retrieved from https://strathprints.strath.ac.uk/60723/1/Reid_etal_BAFA_2017_Intangible_assets_and_determinants_of_fir m.pdf

Ross, S. A., Westerfield, R. W., \& Jordan, B. D. (2010). Fundamentals of Corporate Finance (9th ed.). McGraw-Hill/Irwin, New

York. https://www.academia.edu/15382294/166085925-Ross-Westerfield-Jordan-Fundamentals-of-Corporate-Fin ance-9th-Ed-2010

Salojärvi, S., Furu, P., \& Sveiby, K. E. (2005). Knowledge management and growth in Finnish SMEs. Journal of knowledge management, 9(2), 103-122. https://doi.org/10.1108/13673270510590254

Sartori, S., Latrônico, F., \& Campos, L. (2014). Sustainability and sustainable development: a taxonomy in the field of literature. Ambiente \& Sociedade, 17(1), 1-22. http://dx.doi.org/10.1590/1809-44220003491

SBA. (2014). Frequently Asked Questions about Small Business. SBA Office of Advocacy. March 2014. Retrieved from https://www.sba.gov/sites/default/files/advocacy/FAQ_March_2014_0.pdf

SBA. (2017). Small Business Administration U.S. Small Business Administration, Office of Advocacy. August 2017. Retrieved from https://www.sba.gov/sites/default/files/advocacy/SB-FAQ-2017-WEB.pdf 
Schwab, L., Gold, S., Kunz, N., \& Reiner, G. (2017). Sustainable business growth: exploring operations decision-making. Journal of Global Responsibility, 8(1), 83-95. https://doi.org/10.1108/JGR-11-2016-0031

Seens, D. (2013). Small and Medium-Sized Enterprises Growth Study: Actual vs. Sustainable Growth. Industry Canada. March 2013. Retrieved from https://www.ic.gc.ca/eic/site/061.nsf/vwapj/SMEGrowthStudy-EtudeCroissancePME_eng.pdf/\$file/SMEGr owthStudy-EtudeCroissancePME_eng.pdf

Slaper, T. F., \& Hall, T. J. (2011). The triple bottom line: What is it and how does it work? Indiana Business Review, Spring 2011. pp. 4-8. Retrieved from http://www.ibrc.indiana.edu/ibr/2011/spring/pdfs/article2.pdf

Sridhar, K., \& Jones, G. (2013). The three fundamental criticisms of the Triple Bottom Line approach: An empirical study to link sustainability reports in companies based in the Asia-Pacific region and TBL shortcomings. Asian Journal of Business Ethics, 2(1), 91-111. https://doi.org/10.1007/s13520-012-0019-3

Stancu, I., Stancu, D., Dumitrescu, D., \& Tinca, A. (2015). Sales Forecasting in the Context of Seasonal Activities and Company Sustainable Growth. Amfiteatru Economic, 17(40), 1054. Retrieved from http://ezproxy.upm.edu.my:2087/docview/1700707471/fulltextPDF/F4F876C34B44562PQ/2?accountid=27 932

Stefanikova, L', Rypakova, M., \& Moravcikova, K. (2015). The impact of competitive intelligence on sustainable growth of the enterprises. Procedia Economics and Finance, 26, 209-214. https://doi.org/10.1016/S2212-5671(15)00816-3

Tarek, S. A. (2011). Study of Sustainable Growth Factors of SIE/ Micro-financed Business. World Review of Business Research, 1(4), 142-159. $\quad$ Retrieved from http://www.wrbrpapers.com/static/documents/September/2011/12.\%20Syed.pdf

Thum-Thysen, A., Voigt, P., Bilbao-Osorio, B., Maier, C., \& Ognyanova, D. (2017). Unlocking Investment in Intangible Assets. Discussion paper 047, May 2017. Retrieved from https://ec.europa.eu/info/publications/economic-and-financial-affairs-publications_en

Wakkee, I., Van Der Veen, M., \& Eurlings, W. (2015). Effective Growth Paths for SMEs. The Journal of Entrepreneurship, 24(2), 169-185. https://doi.org/10.1177/0971355715586894

Warren, L. (2004). A systemic approach to entrepreneurial learning: an exploration using story telling. Systems Research and Behavioral Science; Jan/Feb 2004; 21, 1; ABI/INFORM Collection pg. 3-16.

Wolff, J. A., Pett, T. L., \& Ring, J. K. (2015). Small firm growth as a function of both learning orientation and entrepreneurial orientation. International Journal of Entrepreneurial Behavior \& Research, 21(5), 709-730. http://dx.doi.org/10.1108/IJEBR-12-2014-0221

Yazdanfar, D., \& Öhman, P. (2015). The growth-profitability nexus among Swedish SMEs. International Journal of Managerial Finance, 11(4). http://dx.doi.org/10.1108/IJMF-01-2015-0005

Yun, J. J., Jung, W., \& Yang, J. (2015). Knowledge strategy and business model conditions for sustainable growth of SMEs. Journal of Science \& Technology Policy Management, 6(3), 246-262. http://dx.doi.org/10.1108/JSTPM-01-2015-0002

\section{Copyrights}

Copyright for this article is retained by the author, with first publication rights granted to the journal.

This is an open-access article distributed under the terms and conditions of the Creative Commons Attribution license (http://creativecommons.org/licenses/by/4.0/). 